\title{
Statin gyógyszerszedési gyakorlat myocardialis infarctus után Magyarországon
}

\author{
Tomcsányi János dr.
}

Betegápoló Irgalmasrend Budai Irgalmasrendi Kórháza, Budapest

\begin{abstract}
Bevezetés: A statinterápia bizonyítottan az egyik alapköve a cardiovascularis betegségek megelőzésének és kezelésének, ugyanakkor szedésük nagyon gyakran szuboptimális. Primer prevencióban ismerten magas a statint abbahagyók aránya, infarktus után ez az arány nem ismert. Célkituzés: Az akut myocardialis infarctus után történő hazai statinszedési gyakorlat megismerése. Módszer: Az infarktus utáni halálozásra, a statin- és ezetimibadherenciára vonatkozóan az Országos Egészségpénztár 2013-2015-ös adatai alapján végeztünk retrospektív adatgyújtést. Legalább hat hónapos terápiát alapul véve adherensnek tekintettük azokat, akiknél a gyógyszerkiváltás legalább 80\%-os volt. Eredmények: Az infarktus utáni halálozás a 2013-as évet figyelembe véve az infarktus után hat hónappal 12,7\% volt, egy évvel az infarktus után 16,2\%, és két évvel az infarktus után 21,8\%-nak adódott. Szekunder prevencióban a statinadherencia átlagosan elérte a 70\%-ot. A nagy dózisú statinterápia mellett az adherencia jobb volt, mint a közepes dózisok mellett, illetve az ezetimib kombinációval (66\%, illetve 38\% a nagy, illetve közepes dózisok mellett). Ugyanakkor csak a betegek töredéke $(3,6 \%)$ volt statin-ezetimib kombináción. Következtetések: Az első két évben a myocardialis infarctus utáni halálozás napjainkban is igen magas. A statinadherencia sokkal jobb eredményt mutatott az infarktus után, mint a primer prevencióban. Ugyanakkor a kombinációs terápia aránya még nagyon alacsony, amiből arra lehet következtetni, hogy sok betegnél nincsenek az LDL-koleszterin-értékek a céltartományon belül. Orv. Hetil., 2017, 158(12), $443-446$.
\end{abstract}

Kulcsszavak: statinadherencia, myocardialis infarctus, szekunder prevenció, ezetimib, statin-ezetimib kombináció

\section{Adherence to statins in patients with myocardial infarction in Hungary}

Introduction: Statin therapy has proven to be one cornerstone for prevention and treatment of cardiovascular disease, but the clinical application is suboptimal. Adherence to statin therapy in Hungary in primary prevention is very low, but not known in patients with myocardial infarction. Aim: This study was designed to determine the statin and ezetimib adherence after myocardial infarction in respect of total mortality. Method: A retrospective study was carried out based on the National Health Insurance database between 2013-2015. Adherence was measured after minimum 6 months therapy and at least $80 \%$ statin prescription. Results: Total mortality rate after myocardial infarction was $12,7 \%$ after 6 months, 16,2\% after one year and $21,7 \%$ after two years. Statin adherence after myocardial infarction reached $70 \%$. The adherence was higher among patients with high dose than the modest dose statin therapy. Adherence with the combination of statin-ezetimibe therapy was lower than with statin monotherapy. Adherence with modest intensity statin-ezetimibe combination was only $40 \%$. High intensity statin-ezetimibe combination resulted $66 \%$ adherence. Conclusions: The myocardial infarction mortality remain high in the first two years. Adherence to high or modest dose statin is better than in primary prevention. The patient number on statin-ezetimibe combination is very low, which means that lot of patients are not on the target level of LDL cholesterin.

Keywords: statin, adherence, myocardial infarction, ezetimibe, secundary prevention

Tomcsányi, J. [Adherence to statins in patients with myocardial infarction in Hungary]. Orv. Hetil., 2017, 158(12), 443-446.

(Beérkezett: 2016. december 14.; elfogadva: 2017. január 21.) 


\section{Rövidítések}

BNO = Betegségek Nemzetközi Osztályozása; CV = cardiovascularis; HBCs = Homogén Betegségcsoport kórházi esetek osztályozási rendszere; LDL = alacsony sưrúségű lipoprotein; NSTEMI = nem ST-elevációs myocardialis infarctus; STEMI = ST-elevációs myocardialis infarctus

A dyslipidaemia kezelésének elsődleges készítménye több mint 30 éve a statinterápia, ami kedvező hatását a $\mathrm{CV}$-morbiditásra és -mortalitásra mind a primer, mind a szekunder prevencióban kifejti [1]. Annak ellenére, hogy ezen kedvező hatások miatt mind az európai dyslipidaemiás, mind az infarktussal foglalkozó ajánlásokban egyértelmúen elóírják az alkalmazást, a betegek igen jelentôs része vagy nem szed statint, vagy hamar abbahagyja a statin szedését, vagy nem abban a dózisban szedi, ami effektív és ajánlott [2-4]. Az irodalmi adatok szerint a betegek több mint fele abbahagyja a statin szedését a terápia megkezdése után. Elsősorban a primer prevencióra adott statint hagyják el idősebb betegek. Kiss és mtsai publikálták az OEP adatbázisa alapján a statinperzisztenciát 2007-2009 között úgy, hogy a statin, ezetimib és statin-ezetimib fix kombinációt vizsgálták [5]. Az eredmény az lett, hogy a statinszedók egy hónap után már kevesebben vannak, mint $50 \%$, és egy év után alig érik el a 20\%-ot. Simonyi a MULTI GAP 2013-ban arra is felhívja a figyelmet, hogy az orvosadherencia igen fontos szerepet játszik a lipidterápiában, illetve annak hiányosságaiban [6].

Különösen „fájó”, hogy a betegek a coronariaesemény után is elhagyják/csökkentik a nagy dózisú intenzív statinkezelést, annak ellenére, hogy az ajánlások kemény végpontú vizsgálatok alapján nagyon világos útmutatást adnak arra, hogy a betegeknek függetlenül a kiindulási LDL-értéktől, a lehető legnagyobb tolerábilis dózist kell szedniük az atorvastatin vagy rosuvastatin típusú statinból $[2,7,8]$. Hazai viszonylatban Jánosi és mtsa a Nemzeti Szívinfarktus Regiszter adataival hívták fel a figyelmet arra, hogy infarktus után hiába kiváló a kórházi halálozás, az egyéves halálozás már a daganatos betegségeknél is rosszabb [9].

Jelen vizsgálat célja az volt, hogy az akut infarktust elszenvedett beteg statinszedési adherenciáját vizsgálja az OEP adatbázisa alapján, az életkor és statindózisok függvényében figyelembe véve ezen betegek összhalálozási adatait.

\section{Betegek és módszer}

Retrospektív vizsgálat a 2013-2015 közötti időszakban az OEP adatbázisában szereplő akut myocardialis infarctust elszenvedett betegekre vonatkozóan. A betegek 6-12-24 hónapos statin- és statin-ezetimib gyógyszerkiváltásait vizsgáltuk. Külön életkorcsoportok, statindózisok és adherencia szerinti lebontásban is. Adherensnek azt vettük, ha egy beteg legalább $80 \%$-ban kiváltotta a recepteket (minimum hat hónapos időintervallumot figyelembe véve, ami jelen esetben azt jelentette, hogy infarktus után hat hónappal kezdtük mérni az adherenciát).

Habár a vizsgálat elsősorban a statinadherenciára vonatkozott, szükségesnek tünt ezen idő alatti halálozási adatokat is figyelembe venni. Ezért a 2013-2015 közötti időszak összhalálozását is megvizsgáltuk azoknál, akik akut myocardialis infarctust szenvedtek el ebben az időszakban, és magyar biztosítással rendelkeztek. A figyelembe vett HBCs-k a követezők voltak: 2051, 2060, 2070, 2081, 2082, 2110, 1800. A 2110 és 1800 HBCs-k esetén feltétel, hogy azok az I21, I22 vagy I23-as BNO mellett történjenek.

\section{Eredmények}

A demográfiai adatokat az 1 . ábra szemlélteti. Látható, hogy az infarktusok száma az egyes életkori csoportokban nagyjából megegyezik a három egymást követő évben. Az ábrából az is látszik, hogy a 65 év alattiak és felettiek aránya közel azonos, és az életkor alapján történő nagy ugrás az infarktus megjelenésében 50 és 65 év között következik be. Az átlagéletkorok nem nagyon változtak: 66,1 év/2013, 66,5 év/2014, 66,4 év/2015. Az egyéves halálozás a 2013-2014-2015-ös években szintén közel azonosnak adódott: 16,3\%-16,5\%-15,6\%. A legteljesebb halálozási adatokkal a 2013. évben infarktusban elhunytaknál rendelkezünk, amit a 2. ábra mutat be.

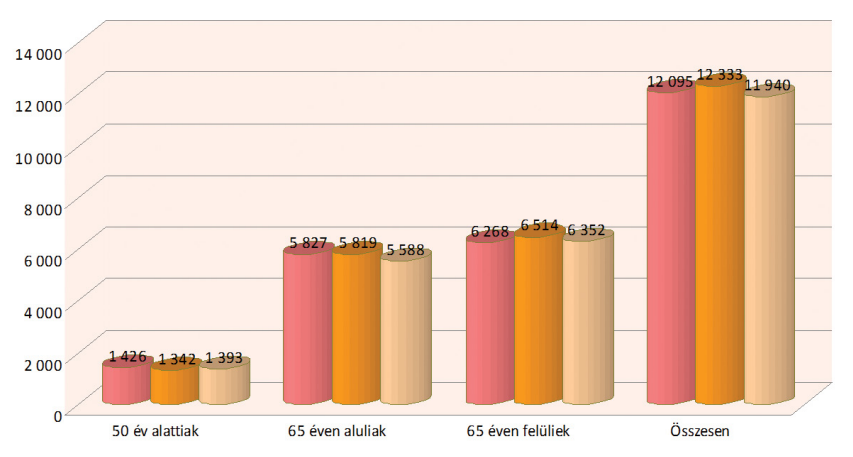

1. ábra $\quad$ A 2013-2015-ben infarktust elszenvedett betegek száma és életkor szerinti megoszlása

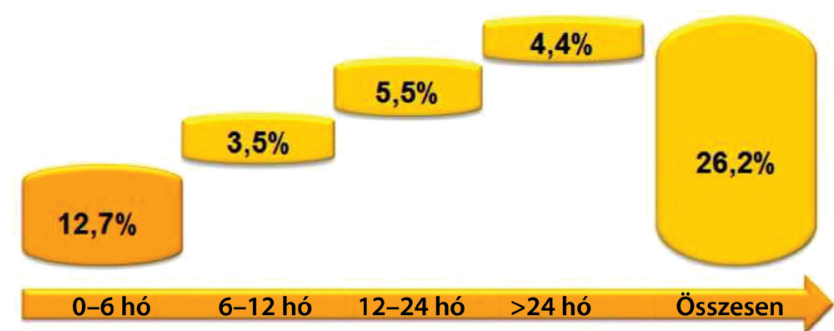

2. ábra $\quad$ A 2013-ban infarktust kapott betegek összhalálozása az idó függvényében. 2016. március 31 -ig történt adatfeldolgozás 


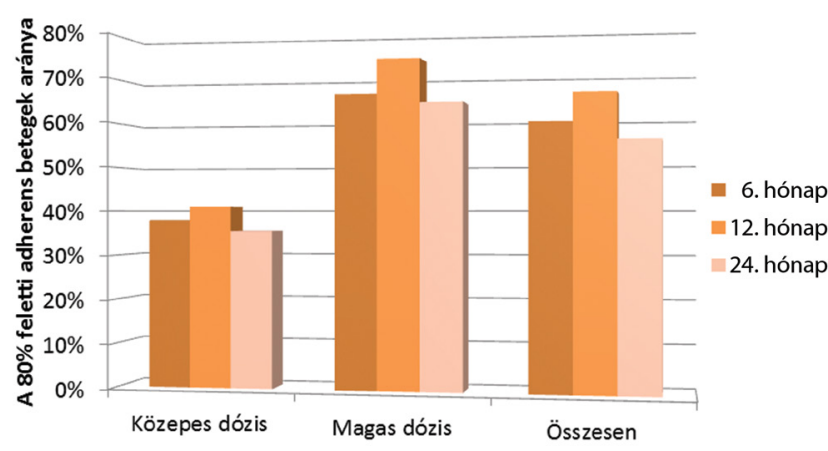

3. ábra 2013-ban beválogatott, adott hónapban életben lévő, statinmonoterápián lévő betegek terápiás dózis és adherencia szerint megoszlása. A nagy dózisú statint a $80 \mathrm{mg}$ atorvastatin és $40 \mathrm{mg}$ rosuvastatin, míg a közepes dózist a $40 \mathrm{mg}$ atorvastatin és 20 mg rosuvastatin jelentette

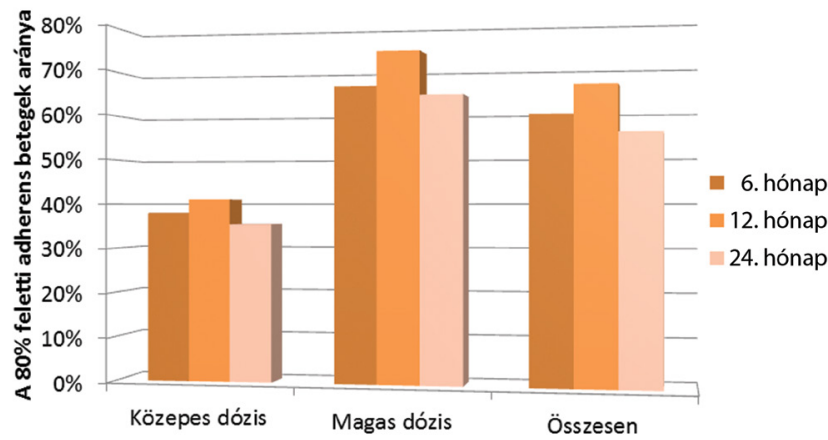

4. ábra $\mid$ Statin-ezetimib kombinációk adherenciája 2013-ban beváloga tott betegekre vonatkozóan. Abszolút számokban a 12. hónapnál a betegszám alacsonyabb, mint a 6 . hónapnál, viszont maga sabb arányt képvisel ez a szám az összes beteghez képest, mint a terápia kezdetekor. Ez okozza azt a látszólagos paradoxont, hogy idővel javul a betegadherencia. Ez a magyarázat igaz a 3 ábrára is

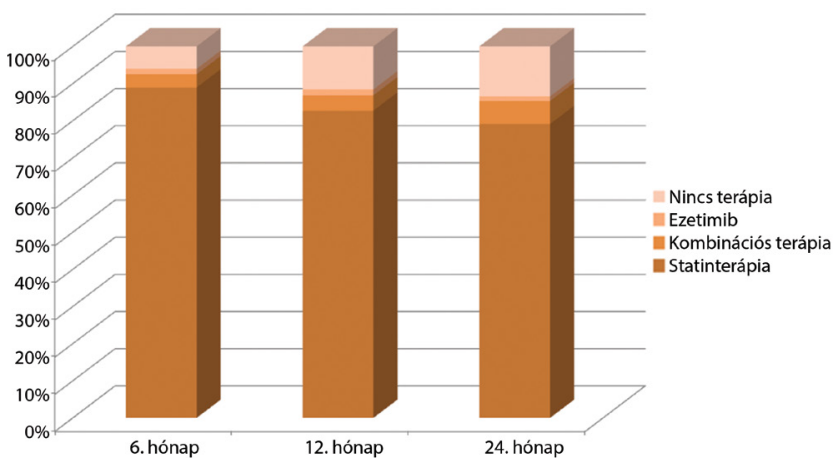

5. ábra | A betegek lipidcsökkentő terápiájának változásai

A statinadherenciát a 2013-as évre vonatkoztatva tudjuk a legteljesebben megadni, amit a 3. ábra illusztrál, dózisok és időbeni bontásokban. A 4. ábra az ezetimibbel való kiegészítés utáni adherenciákat mutatja. Az 5 . ábrán a lipidcsökkentőt szedők aránya és megoszlása látszik az eltelt idő függvényében.
1. táblázat $\mid$ Statinadherencia a coronariabetegség szekunder prevenciójában a regiszterek alapján

\begin{tabular}{lccll}
\hline Szerzó & Év & Betegszám & $\begin{array}{l}\text { Statin- } \\
\text { adherencia } \\
(\%)\end{array}$ & $\begin{array}{l}\text { Utánkövetés } \\
(\text { év })\end{array}$ \\
\hline Ho et al. [14] & $2000-2005$ & 13596 & 74 & 4,1 \\
$\begin{array}{l}\text { Munter et al. } \\
\text { [15] }\end{array}$ & $2007-2009$ & 2695 & 63,8 & 1 \\
Ho et al. [16] & $2003-2004$ & 2498 & 78,1 & 1 \\
Jánosi [9] & $2013-2014$ & 14843 & 51,8 & 1 \\
\hline
\end{tabular}

\section{Megbeszélés}

Akut coronariaszindróma után az életmódváltozás és nem lipidcsökkentő rizikófaktorok modifikációja mellett az agresszív statinterápiával további mortalitáscsökkenés érhető el [10]. A jelen OEP-összmortalitási adatok az infarktusregiszterhez hasonlóan igen magas halálozási eredményeket adnak. Éppen ezért nagyon fontos annak a vizsgálata, hogy az infarktust elszenvedett és a korai kórházi mortalitást elkerülő betegeknél megtörténik-e a statin folyamatos szedése és ezzel sikerül-e optimális LDL szintet/csökkenést elérni. Ez ma már nem egyszerü, mert nem elég a nagy dózisú atorvastatin vagy rosuvastatin alkalmazása, hanem a célértéket el nem ért esetekben az IMPROVE-IT alapján további ezetimibkiegészítés javasolt [11]. A rendelkezésünkre álló nemzetközi és hazai regiszteradatok $50 \%$ feletti adherenciát mutatnak a szekunder prevencióban (1. táblázat). Korábbi hazai vizsgálatok igen lesújtó eredményeket mutattak a hazai primer és szekunder prevenciós gyógyszerszedési szokásokról. Éppen ezért tartottuk fontosnak, hogy megvizsgáljuk, hogy ebben az igen magas rizikójú csoportban milyenek a statinadherenciás adatok. Sajnos az ezetimib eredményei a nemrég megjelent IMPROVE-IT miatt még nem épülhettek be a napi rutinba, így itt a statisztika erejét rontotta az alacsony betegszám. Ugyanakkor azt is fontos megemlíteni, hogy nem elsősorban a szociális státusz az, ami meghatározza a beteg gyógyszerszedési szokásait, gyógyszerhúségét, hanem a betegre szánt idő és meggyőzés [12, 13].

\section{A vizsgálat hiányosságai}

A fenti vizsgálati módszernek számos hiányossága van (amiken csak részben segít az utóbbi években bevezetett infarktusregiszter):

- A halálozásnál csak összhalálozást tudunk és nem cardiovascularis halálozást.

- Az infarktus fajtájára (NSTEMI versus STEMI) vonatkozóan nincs információnk, ahogyan a revascularisatio megtörténtére és sikerességére vonatkozóan sincsen, ami pedig nagyban befolyásolja a mortalitást.

- Az első hat hónapban - értelemszerúen - nem lehet perzisztenciát számolni. 
- Csak gyógyszerkiváltást és nem gyógyszerszedést, illetve gyógyszerhatékonyságot lehetett vizsgálni, ezért:

- nem tudjuk, hogy mennyien hagyták abba a statin szedését mellékhatás miatt;

- nem tudjuk, hogy a nonadherencia mennyiben múlt a betegen és mennyiben az orvoson, beleértve a kórházi elbocsátáskor szereplő statinjavaslatot és dózismegoszlást;

- nem tudjuk a betegek szociális státuszát és ennek szerepét a nonadherenciában.

\section{Következtetések}

Habár az infarktus utáni statinadherencia javult az elmúlt években, az összhalálozás továbbra is magas. A halálozás, illetve a CV-események száma az LDL-célérték elérésével, illetve intenzív csökkentésével javítható. Fontos a célértéket el nem érő betegeknél a nonstatin terápiás kombinációk (ezetimib, PCSK9-gátlók) alkalmazása. Ehhez a betegek szoros utánkövetése és gyógyszertitrálása szükséges.

Anyagi támogatás: A közlemény megírásával kapcsolatban a szerző anyagi támogatásban nem részesült.

A szerző a cikk végleges változatát elolvasta és jóváhagyta.

Érdekeltség: A szerzőnek nincsenek érdekeltségei.

\section{Irodalom}

[1] Cholesterol Treatment Trialists, Fulcher, J., O'Connell, R., Voysey, $M$., et al.: Efficacay and safety of LDL-lowering therapy among men and women: metaanalysis of induvidual data from 174000 participants in 27 randomised trials. Lancet, 2015, 385(9976), 1397-1405

[2] Catapano, A. L., Grabam, I., De Backer, G., et al.: 2016 ESC/ EAS guidelines for the management of dyslipidaemias. Eur. Heart J., 2016, 37(39), 2999-3058.

[3] Steg, P. G., James, S. K., Atar, D., et al.: ESC Guidelines for the management of acute myocardial infarction in patients presenting with ST-segment elevation. Eur. Heart J., 2012, 33(20), 2569-2619.

[4] Mark, L., Paragh, G., Karadi, I., et al.: How can we futher improve the LDL-cholesterol target level achievement rate based on the Hungarian MULTI GAP 2011 study results and consid- ering the new European dyslipidaemia guidelines? Arch. Med. Sci., 2012, 8(4), 608-613.

[5] Kiss, Z., Nagy, L., Reiber, I., et al.: Resistence with statin therapy in Hungary. Arch. Med. Sci., 2013, 9(3), 409-417.

[6] Simonyi, G.: Lipid-lowering therapy and patient adherence in the MULTI GAP 2013 trial. [Lipidcsökkentő terápia és betegadherencia a MULTI GAP 2013 vizsgálat tükrében.] Orv. Hetil., 2014, 155(17), 669-675.

[7] Rosenson, R. S., Kent, S. T., Brown, T. M., et al.: Underutilization of high-intensity statin therapy after hospitalization for coronary heart disease. J. Am. Coll. Cardiol., 2015, 65(3), 270-277.

[8] Ho, P. M., Spertus, J. A., Masoudi, F. A., et al.: Impact of medication therapy discontiunation on mortality after myocardial infarction. Arch. Intern. Med., 2006, 166(17), 1842-1847.

[9] Jánosi, A., Ofner, P.: National Myocardial Infarction Registry of Hungary. [Nemzeti Szívinfarktus Regiszter.] Orv. Hetil., 2014, 155(19), 740-744.

[10] Navarese, E. P., Kowalewski, M., Andreotti, F., et al.: Meta-analysis of time-related benefits of statin therapy in patients with acute coronary syndrome undergoing percutaneous coronary intervention. Am. J. Cardiol., 2014, 113(10), 1753-1764.

[11] Cannon, C. P., Blazing, M. A., Giugliano, R. P., et al., for the IMPROVE-IT Investigators: Ezetimibe added to statin therapy after acute coronary syndromes. N. Engl. J. Med., 2015, 372(25), 2387-2397.

[12] Rasmussen, J. N., Gislason, G. H., Rasmussen, S., et al.: Use of statins and beta-blockers after acute myocardial infarction according the income and education. J. Epidemiol. Community Health, 2007, 61(12), 1091-1097.

[13] Mayer, O. Jr., Simon, J., Heidrich, J., et al.: Educational level and risk profile of cardiac patients in the EUROASPIRE II substudy. J. Epidemiol. Community Health, 2004, 58(1), 47-52.

[14] Ho, P. M., Magid, D. J., Setterley, S. M., et al.: Medication nonadherence is associated with a broad range of adverse outcomes in patients with coronary artery disease. Am. Heart J., 2008, 155(4), 772-779.

[15] Munter, P., Yun, H., Shama, P., et al.: Ability of low antihypertensive medication adherence to predict statin discontinuation and low statin adherence in patients initiating treatment after a coronary event. Am. J. Cardiol., 2014, 114(6), 826-831.

[16] Ho, P. M., Spertus, J. A., Masoudi, F. A., et al.: Impact of medication therapy discontinuation on mortality after myocardial infarction. Arch. Intern. Med., 2006, 166(17), 1842-1847.

(Tomcsányi János dr., Budapest, Árpád fejedelem u. 7., 1027 e-mail: tomcsanyij@gmail.com)

Az Orvosi Hetilap egyes számai megvásárolhatók a Mediprint Orvosi Könyvesboltban.

Cím: Budapest V., Múzeum krt. 17. - Telefon: 317-4948 